\title{
Recurrence of febrile convulsions
}

\author{
SHEILA J. WALLACE \\ From the Department of Child Life and Health, University of Edinburgh
}

\begin{abstract}
Wallace, S. J. (1974). Archives of Disease in Childhood, 49, 763. Recurrence of febrile convulsions. Of 116 children who did not receive anticonvulsants after their first febrile convulsion, $55(47 \%)$ had a recurrence with a subsequent febrile illness. A significantly increased risk is present in (a) those with persistent neurological abnormality, (b) those who have had a complicated initial fit, (c) males with a positive history of convulsive disorder in parents and/or sibs, and (d) females with age of onset of less than 19 months. It is suggested that the findings could be used for selecting children with a high rate of recurrence for continuous anticonvulsant therapy.
\end{abstract}

A febrile convulsion is defined here as any convulsive episode occurring in association with any feverish illness. It is recognized that serious sequelae may result (Lennox, 1949; Lennox, 1953; Schmidt, 1958; Gastaut et al., 1960; Ounsted, Lindsay, and Norman, 1966; Falconer, Serafetinides, and Corsellis, 1964). Further, the greater the number of episodes, the more commonly is the convulsion severe, i.e. lasting longer than 30 minutes, or mainly or solely unilateral (LennoxBuchtal, 1973). Moreover, children with repeated fits with fever are more likely to develop spontaneous attacks (Livingston, Bridge, and Kajdi, 1947; Millichap, 1968). This study reports an examination of factors which might predispose to recurrence of febrile convulsions in 116 children who were admitted to the Royal Hospital for Sick Children, Edinburgh, between December 1964 and August 1966.

\section{Patients and methods}

Between December 1964 and August 1966, 134 consecutive children with febrile convulsions were admitted to hospital. They were examined at the time of admission and followed up continuously for a minimum of 18 and a maximum of 38 months. Recurrence of febrile convulsions within this time is assessed in those 116 children ( 72 males, 44 females) who did not receive long-term anticonvulsants after the first attack. The children are grouped initially according to the following criteria: sex, pregnancy and perinatal history, persisting neurological abnormality, family history of convulsive disorder in parents and/or sibs. The significance of differences in recurrence rates between different groups was tested by the $\chi^{2}$ test. After division into groups according to, and therefore

Received 8 March 1974. with correction for, the above criteria, the following additional factors were examined. (1) Age at onset. (2) Type of initial fit: (i) complicated-one fit lasting at least 30 minutes, or repeated seizures within the first episode; (ii) simple-single fit lasting less than 30 minutes. (3) Presence or absence of viral infection in the 44 children in whom satisfactory studies had been completed. If either sex showed more susceptibility to a particular factor, the findings in males and females are considered separately. Similar trends in both sexes are reported together.

\section{Results}

Of the 116 children, $55(47 \%)$ had a fit with a subsequent illness. By itself, sex did not influence recurrence. 34 of 72 males and 21 of 44 females had further fits. Age at onset appeared to be very important in females and less important in males (Fig. 1 and 2). Fits recurred in 17 of 26 females who had their first attack before 19 months of age, and in 4 of 18 whose onset was later $(P<0.005)$. Only 18 of 34 males with the first fit before 19 months, and as many as 16 of the 38 with later onset had recurrences (no significant difference). With early onset, males with a positive family history were more likely to have a subsequent fit than those whose family history was negative, but the numbers involved were too small for statistical analysis to be valid. The presence of at least two 'significant' perinatal abnormalities (Wallace, 1972) did not significantly affect the liability to recurrence. Attacks were repeated in 14 of 25 children with at least two, and in 41 of 91 children with not more than one, perinatal problem. Persisting neurological disorder caused a significant increase in the recurrence rate. 38 of 68 children with and 17 of 48 without neurological disorder persisting longer than 

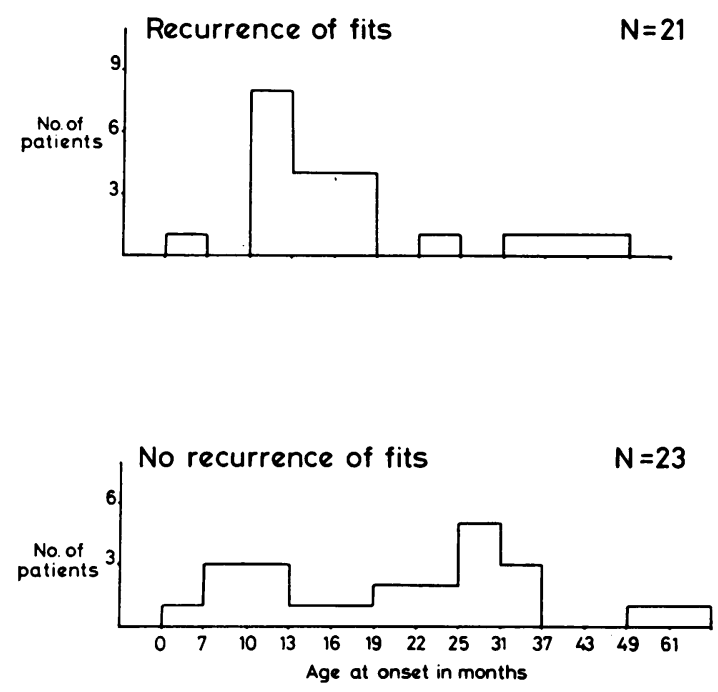

FIG. 1.-Age at initial fit related to recurrence of febrile convulsions in females.

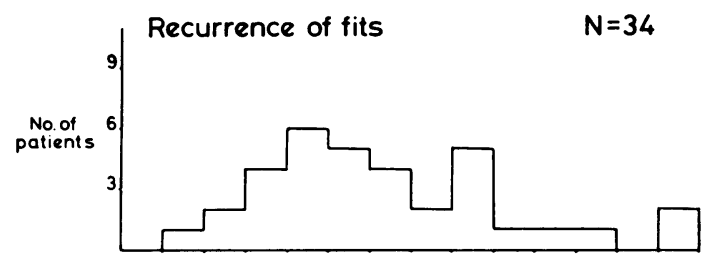

1

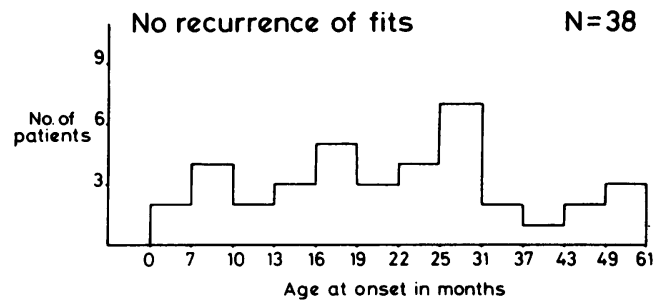

FIG. 2.-Age at initial fit related to recurrence of febrile convulsions in males.

the initial illness had further fits. In males, the presence of a convulsive disorder in sibs or parents was significantly associated with increased recurrence. 19 of 29 males with and 15 of 43 without a positive family history had another convulsion $(P<0.02)$. A positive family history was not associated with increased recurrence in females. 4 of 9 with a positive and 17 of 35 with a negative family history had another fit. The type of fit significantly affected the prognosis. If the initial episode was complicated, 36 of 60 children had another attack compared with 19 of 56 whose first fit had been simple. Definite evidence of viral infection did not significantly alter the outcome. 9 of 20 children with positive and 8 of 24 with negative findings in the initial attack had a fit with a subsequent febrile illness. The Table summarizes the results.

TABLE

Influence of factors examined on recurrence of febrile convulsions

\begin{tabular}{l|c}
\hline \multicolumn{1}{c|}{ Factor } & $P$ \\
\hline $\begin{array}{l}\text { Sex } \\
\text { Age at onset less than } 19 \mathrm{mth}\end{array}$ & $\mathrm{NS}$ \\
Males & $\mathrm{NS}$ \\
$\begin{array}{l}\text { Females } \\
\text { Presence of at least } 2 \text { 'significant' perinatal } \\
\text { abnormalities }\end{array}$ & $<0.005$ \\
$\begin{array}{l}\text { Persisting neurological disorder } \\
\text { History of convulsive disorder in sibs and/or } \\
\text { parents }\end{array}$ & $\mathrm{NS}$ \\
$\begin{array}{l}\text { Males } \\
\text { Females }\end{array}$ & \\
Complicated initial fit & $<0.05$ \\
Positive viral findings & NS \\
& $<0.05$ \\
\hline
\end{tabular}

NS, not significant.

\section{Discussion}

The overall recurrence rate for febrile convulsions of $47 \%$ is similar to the average of $44 \%$ found in a review of 25 publications (Millichap, 1968). Previous reports have suggested that one or other sex was more liable to recurrence. Frantzen et al. (1970) showed females to be more susceptible, whereas males had a poorer prognosis for repeated episodes in the series of Doose et al. (1966). Males and females seemed equally vulnerable in this investigation. Analysis of features which affect the sexes differently suggests that the age at onset and family history composition of any group examined might alter the recurrence rate when the influence of sex is being discussed.

Girls, but not boys, who had their first fit before 19 months of age were significantly more likely to have subsequent fits. Taylor and Ounsted (1971) reported that girls are liable to start having febrile convulsions at an earlier age than boys. In considering recurrence in relation to age of onset in boys, the critical time might be expected to be later than 19 months, but this could not be determined from the histograms (Fig. 2). Early onset has been associated previously with increased risk of another fit (Lennox, 1949; Bamberger and Matthes, 1959). Frantzen et al. (1970) reported that if the first fit occurred before 14 months, subsequent attacks are significantly commoner. They did not report 
recurrence by sex and age at onset, and in adding to their consecutive series unspecified children to supplement poorly represented age groups, could have acquired a disproportionate number of younger girls resulting in overemphasis on the importance of age at onset for the group as a whole.

Abnormalities of the pregnancy and perinatal period did not affect recurrence in the children studied. The importance of such abnormalities has rarely been examined. A higher incidence of repeated episodes was found in 'brain-damaged' children in the series of Bamberger and Matthes (1959). However, Lennox (1953) found at least ten episodes of febrile convulsions commoner in 'non-brain damaged', and a single febrile convulsion commoner in 'brain-damaged' children, but the relation to other undesirable sequelae was not stated.

If neurological dysfunction was present clinically, this significantly increased the risk of recurrence. Previous series have tended to ignore clinical neurological findings. Though a fit is necessarily an episode of acute cerebral disturbance, it has even been suggested that neurological examination is unnecessary (Millichap, 1968). The findings here indicate that it seems of importance.

A positive family history was significantly associated with increased recurrence in males only. Children with positive family history have repeatedly shown a greater liability to repeated febrile convulsions (Lennox, 1949; Bamberger and Matthes, 1959; Doose et al., 1966; Frantzen et al. 1970). Different risks for males and females have not previously been reported. Frantzen et al. (1970), finding that under the age of 13 months there was no correlation between recurrence and family history, did not state the sex composition of this group, though it is likely to have contained a relatively high proportion of females.

Complicated initial seizures were significantly associated with recurrence of febrile convulsions whether or not persistent clinical neurological abnormality was found. Ounsted, et al. (1966) and Corsellis (1971) have emphasized the danger of changes subsequent to brain hypoxia if fits are prolonged. It can be postulated that even in the absence of clinical findings of neurological abnormality there may be sufficient alteration in cerebral structure to increase the risk of a further febrile convulsion.

Evidence from a combined EEG and virological study suggests many children with febrile convulsions could be suffering from viral encephalitis (Wallace and Zealley, 1970). Lennox-Buchtal (1973) has suggested that children who have had a central nervous system infection might have a higher incidence of epilepsy. Frantzen (1971), however, did not find a different rate of recurrence of febrile convulsions in children with or without cells in the spinal fluid at the time of the acute illness. Nor was a proven viral infection apparently of importance for recurrence in this series.

If both the likelihood of a fit being severe or starting without fever increases with the number of febrile convulsions experienced, it is suggested that the present findings could be used as a basis for selecting children with a high risk of recurrence, and for placing them on continuous prophylactic anticonvulsants.

All the paediatricians at the Royal Hospital for Sick Children, Edinburgh, kindly allowed their patients to be studied. In particular, Dr. T. T. S. Ingram has given continuous encouragement. A grant was received from the fund given to the Universitv of Edinburgh by the Distillers Company.

\section{REFERENCES}

Bamberger, P., and Matthes, A. (1959). Anfalle im Kindesalter, p. 413. Karger, Basle.

Corsellis, J. A. N. (1971) Brain Hypoxia, p. 263 . Ed. by J. B. Brierley and B. S. Meldrum. Clinics in Developmental Medicine 39/40. Heinemann, London.

Doose, H., Petersen, C. E., Volzke, E., and Herzberger, E. (1966). Fieberkrämpfe und Epilepsie. I. Atiologie, klinisches Bild und Verlauf der sogenannten Infekt-oder Fieberkämpfe. Archiv für Psychiatrie und Nervenkrankheiten, 208, 400.

Falconer, M. A., Serafetinides, E. A., and Corsellis, J. A. N. (1964) Etiology and pathogenesis of temporal lobe epilepsy. Archives of Neurology, 10, 233.

Frantzen, E. (1971). Spinal findings in children with febrile convulsions. Epilepsia, 12, 192.

Frantzen, E., Lennox-Buchtal, M. A., Nygaard, A., and Stene, J. (1970). A genetic study of febrile convulsions. Neurology, 20, 909.

Gastaut, H., Poirier, F., Payan, H., Salamon, G., Toga, M., and Vigouroux, M. (1960). H.H.E. syndrome. Hemiconvulsions, hemiplegia, epilepsy. Epilepsia, 1, 418.

Lennox, M. A. (1949). Febrile convulsions in childhood. Thei relationship to adult epilepsy. Fournal of Pediatrics, 35, 427.

Lennox, W. G. (1953). Significance of febrile convulsions. Pediatrics, 11, 341.

Lennox-Buchtal, M. A. (1973). Febrile convulsions. A reappraisal. (Electroencepholography and Clinical Neurophysiology, Suppl. 32 , p. 91.) Elsevier, Amsterdam.

Livingston, S., Bridge, E. M., and Kajdi, L. (1947). Febrile convulsions; a clinical study with special reference to heredity and prognosis. 'fournal of Pediatrics, 31, 509.

Millichap, J. G. (1968). Febrile Convulsions, p. 90. Macmillan, New York.

Ounsted, C., Lindsay, J., and Norman, R. (1966). Biological Factors in Temporal Lobe Epilepsy, p. 125. Clinics in Developmental Medicine No. 22. Heinemann, London.

Schmidt, R. P. (1958). Sequelae of febrile convulsions. Medical Clinics of North America, 42, 389.

Taylor, D., and Ounsted, C. (1971). Brain Hypoxia, p. 266. Ed. by J. B. Brierley and B. S. Meldrum. Clinics in Developmental Medicine 39/40. Heinemann, London.

Wallace, S. J. (1972). Aetiological aspects of febrile convulsions. Archives of Disease in Childhood, 47, 171.

Wallace, S. J., and Zealley, H. (1970). Neurological electroencephalographic, and virological findings in febrile children. Archives of Disease in Childhood, 45, 611 .

Correspondence to Dr. S. J. Wallace, Department of Child Health, University Hospital of Wales, Heath Park, Cardiff CF4 4XN. 